\title{
EXPERIMENTAL STUDY OF ANCIENT ADMIXTURE AND NATURAL FIBRE IN CONCRETE
}

\author{
S.Karthikeyan ${ }^{1}$, A.A.Elangovan ${ }^{2}$ \\ ${ }^{1}$ Assistant Professor, Civil Engineering, Velammal Engineering college, Tamilnadu,India \\ ${ }^{2}$ Assistant Professor,Civil Engineering, GRT Institute of Engineering and Technology,Tamilnadu,India
}

\begin{abstract}
In the ancient times they had utilized the materials like egg, blood, animal fat, cactus extract in the concrete as admixtures. Generally the admixtures having specific characteristics as accelerating, retarding, air entraining and water reducing abilities. In this study we utilized the ancient admixture as egg albumen and natural fiber as coir fiber in concrete. To identify the characteristics of these materials belonging to the very distant past and no longer existence in the current concrete industry, so that we conduct the experiment with natural fiber and ancient admixture in concrete to determine the effect of concrete and egg albumen is the material which had been used in the distant past and addition of coir fiber for expecting the concrete should have better results. This experiment includes the specimens with 0.2percent of natural fiber and 2percent of ancient admixture as ECI , 0.4 percent of natural fiber and 4 percent of ancient admixture as EC2, 0.6 percent of natural fiber and 6 percent of ancient admixture as EC3 and control mix. Mix design to be prepared for M20 concrete. The concrete specimens were made and tested for hardened concrete test. Finally compare the results with all the specimens including control mix.
\end{abstract}

Key Words: Egg albumen, coir fiber, cement, and aggregate.

\section{INTRODUCTION}

Concrete is a mixture of four materials. Concrete is set by some reaction between Portland cement and water. From past history of concrete in third century Romans used the concrete to construct temples where the concrete made from broken stone, lime and sand. In this study we are utilizing the ancient admixture as egg albumen and natural fiber as coir fiber. The addition of natural fiber for improving the behavior of the concrete and addition of ancient admixture as certainly it results a better bond between the concrete materials as prescribed in the ancient times. According to $\mathrm{M}$. Brahmakuinaret al. (2005) [1], using plant fiber it gives many advantages. Some of the advantages are cheaper in cost, good strength, good thermal properties, tool wear is less, and process of recycling is done without violating the atmosphere. Beside natural fiber, ancient admixture added into the concrete to test its strength and performance. Ancient admixture contains high percentage of protein composition which influenced the cement properties when both were added together. For this study, the ancient admixture was mixed to make it become foam before added into the concrete mixing process which increased the strength of the concrete. [1] gives the good results of using coir fiber as a composite materials. Here we can conclude the coir fiber is act as a good concrete material so we can use this material for further study.

\subsection{Material Problem Statement}

Most of the tropical countries especially in Asia like Thailand, Philippines and Malaysia are disposed the huge amount of agricultural waste around the world. A survey performed by Agricultural Ministry of India Due to that a survey performed by the Agricultural Ministry of India, there are about 156,000 hectares of coconut plantation in India. Once if the waste cannot disposed properly it would be a serious social and environmental issue. Utilize this waste materials by treating them by waste to wealth. The coconut fiber is the useful material in the construction. The another material egg albumen that wasted by the bakery so it is considered as a waste material. There is a lack of research perspective in egg albumen. In all over the world the material used for concrete is a majorly used material. So we need to control the materials which used for concrete and we need to find out the alternative materials for concrete materials.

\subsection{Scope of work}

In this study of experiment we were casted 3 nos of cube of size $150 \mathrm{~mm} \times 150 \mathrm{~mm} \times 150 \mathrm{~mm}$ for compressive strength, 3 nos of cylinder of size $150 \mathrm{~mm}$ dia and $300 \mathrm{~mm}$ long for split tensile test and 3 nos of beam prism of size $500 \mathrm{~mm} x$ $100 \mathrm{~mm} \times 100 \mathrm{~mm}$ for flexural strength. The number of specimens that needed for this experiment was shown in the Table 1. The number of mix specimens that prepared for this experiment were the EC1 added with $0.2 \%$ of the natural fibre and $2 \%$ of ancient admixture, EC2 added with $0.4 \%$ natural fibre and $4 \%$ of ancient admixture and the EC3 added with $0.6 \%$ natural fibre and $6 \%$ of ancient admixture and Control mix was M20 concrete as per code provisions. The tests that were carried out for this experiment were cube compressive test, tensile test and bending strength test which would be performed at the concrete laboratory of Civil Engineering. The mix ratio for this experiment was $1: 1.44: 2.54$ (cement : fine aggregate : coarse aggregate) and the concrete density used as $24 \mathrm{kN} / \mathrm{m}^{3}$ 
with concrete strength of $20 \mathrm{~N} / \mathrm{mm}^{2}$. The materials used in this experiment were natural fibre, ancient admixture, sand, cement, coarse aggregate and water. Number of mix specimens casted for testing was tabulated in Table -1 .

Table -1: Number of mix specimens casted for testing.

\begin{tabular}{|c|c|c|c|c|c|c|c|c|}
\hline $\begin{array}{c}\text { Mix } \\
\text { specimens }\end{array}$ & \multicolumn{2}{|c|}{ EC1 } & \multicolumn{2}{|c|}{ EC2 } & \multicolumn{2}{c|}{ EC3 } & \multicolumn{2}{c|}{$\begin{array}{c}\text { Control } \\
\text { mix(M20) }\end{array}$} \\
\hline Curing days & 7 & 28 & 7 & 28 & 7 & 28 & 7 & 28 \\
\hline $\begin{array}{c}\text { Compression } \\
\text { test }\end{array}$ & 3 & 3 & 3 & 3 & 3 & 3 & 3 & 3 \\
\hline $\begin{array}{c}\text { Split tensile } \\
\text { test }\end{array}$ & 3 & 3 & 3 & 3 & 3 & 3 & 3 & 3 \\
\hline $\begin{array}{c}\text { Flexure test } \\
\text { Coxury }\end{array}$ & 3 & 3 & 3 & 3 & 3 & 3 & 3 & 3 \\
\hline
\end{tabular}

\section{Materials Used}

Course aggregate, fine aggregate, cement, natural fiber and egg albumen are used for preparation of specimens.

\subsection{Natural Fibre}

The admixtures used in this experiment were utilized from locally available materials in forms of industries and the collected materials are allocated uniformly and make them uniform by forming shape to the fibers in the mode of machine cutting then the fibers spotted as uniform shapes and it was shown in Fig -1 .

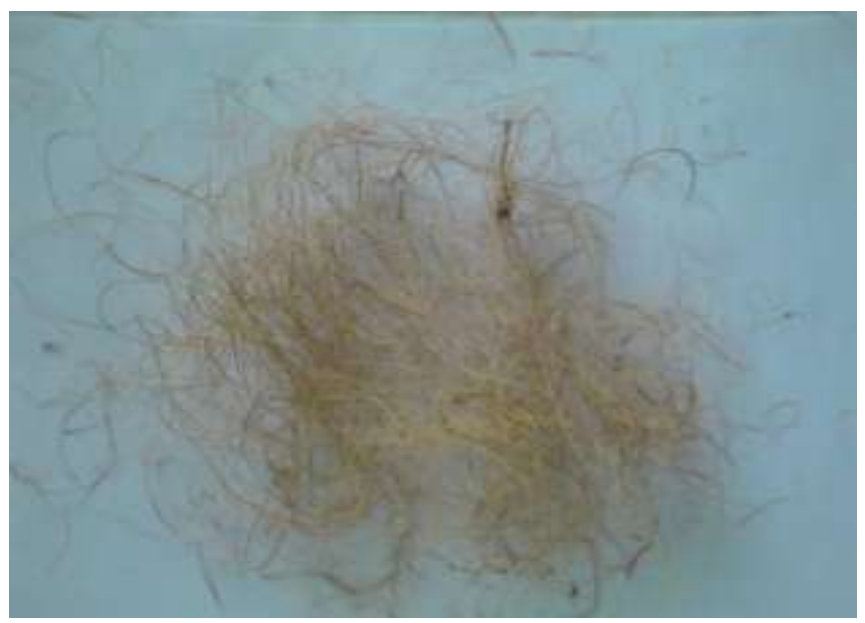

Fig -1: Coir fiber

\subsection{Ancient Admixture}

The egg albumen is improved properties of concrete, when mix with concrete the water is reduced. In ancient days our ancestors utilized the egg albumen as binding material so here we can assumingly conclude the egg albumen representing as a good bonding material.The bond strength increased by adding egg albumen in concrete as admixture. and it was shown in Fig -2.

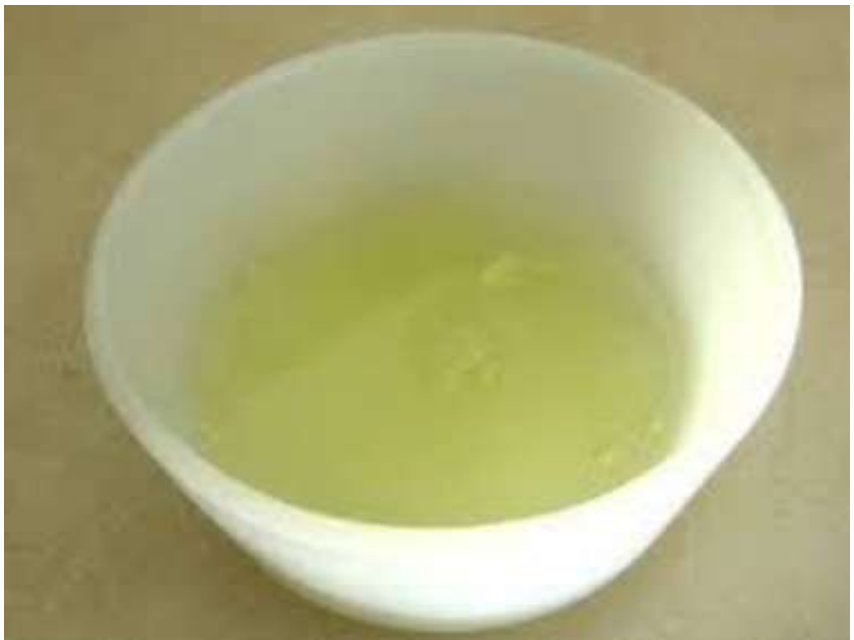

Fig -2: Egg albumen

\section{Experimental Investigation}

\subsection{Design Mix}

The mix design was done as per the indian standard codal provisions to get a target strength of $20 \mathrm{Mpa}$.

\subsection{Curing Of Specimens}

Specimens are casted as per the mix design and kept for 28 days of curing. It was shown in Fig -3.

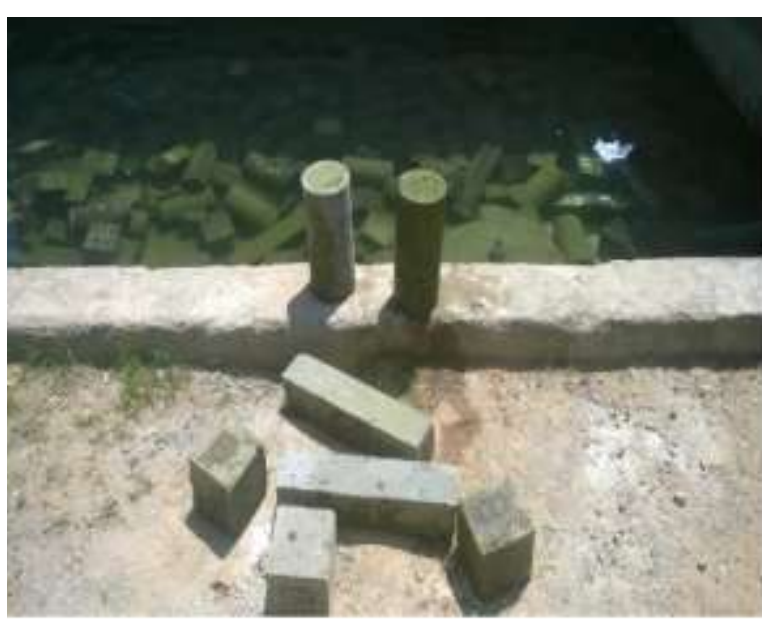

Fig -3: Curing of specimens

\subsection{Test of Specimens}

The test on hardened concrete to be conducted and it described below.

\subsubsection{Cube Compressive Strength Test}

A cube set of specimens $150 \mathrm{~mm}$ X $150 \mathrm{~mm}$ X $150 \mathrm{~mm}$ are used and its depends upon the size of aggregate. Based on Indian Standard specifications, the test to be conducted on cubes with different age of curing and test setup was shown in Fig -4 . 


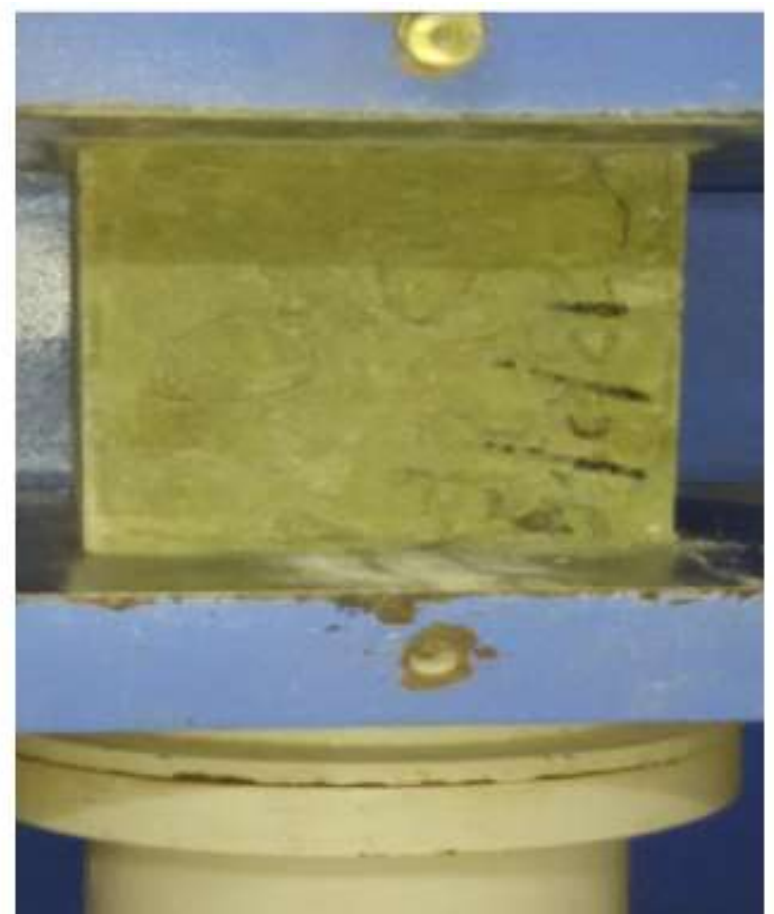

Fig -4: Compressive strength test setup

\subsubsection{Bending Strength Test On Beam}

As per the concept concrete is weak in tension strong in compression. However Size of beam $10 \mathrm{~cm}$ X $50 \mathrm{~cm} \mathrm{X} 10 \mathrm{~cm}$. and test was done to the beam as per the code IS provisions. Test setup as shown in Fig -5 .

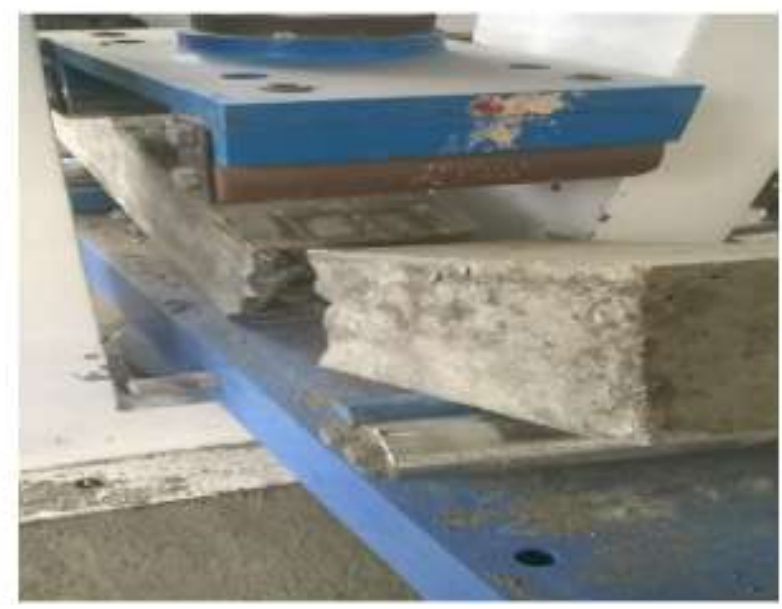

Fig -5: Flexural strength test setup

\subsubsection{Tensile strength test on cylinder}

The split tensile strength is one of the important and peculiar test for concrete to determine the basic properties of concrete in indirect way. Measuring the tensile strength in concrete is such a difficult job so we are conducting a indirect test to find out the tensile strength of concrete in compression testing machine. Here we made cylindrical mould to make a concrete specimen and the cylinder was set up in testing machine with cylinder case then the testing was done as per Indian standards and the test setup was shown in Fig -6 .

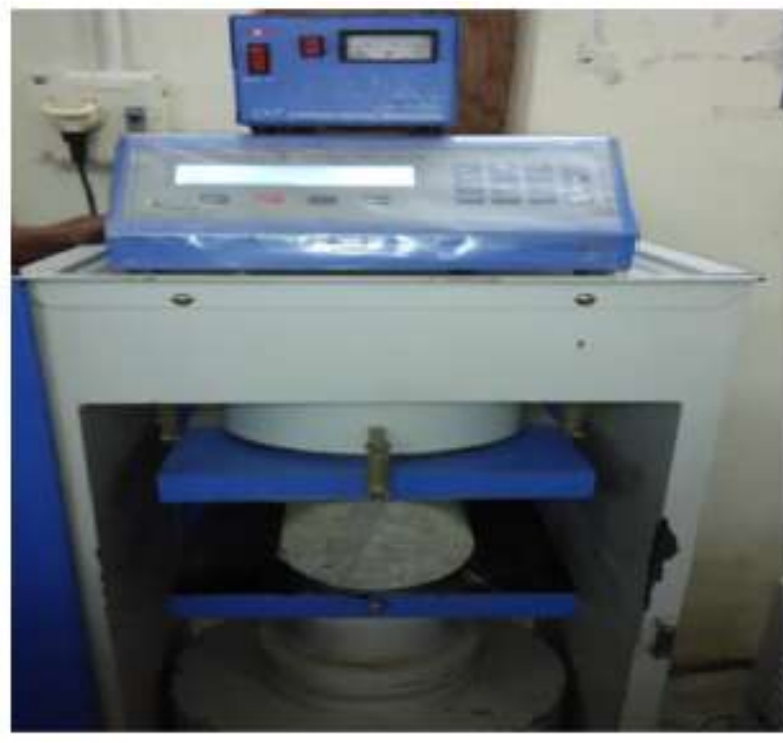

Fig -6: Split tensile strength test setup

\section{FINAL REPORT}

\subsection{Concrete Cube Strength}

During the laboratory work, the $0.2 \%$ natural fiber $+2 \%$ ancient admixture, and $0.4 \%$ natural fiber $+4 \%$ ancient admixture and $0.6 \%$ natural fibre $+6 \%$ ancient admixture added into concrete. Total 108 samples were prepared for testing and compared, 36 samples for $0.2 \%$ natural fiber + $2 \%$ ancient admixture added with concrete (Mix A), 36 samples for $0.4 \%$ natural fiber $+4 \%$ ancient admixture added with concrete (Mix B), 36 samples for $0.6 \%$ natural fiber $+6 \%$ ancient admixture added with concrete (Mix C) and 36 samples for normal concrete. The compression test and flexural test were tested on the samples for 7 and 28 days after the curing process. The materials used during the experiment were cement, water, fine sand, ancient admixture and natural fiber. The mix ratio for these specimens were 1:1.44:2.54 (cement, fine aggregate, coarse aggregate) and the $0.2 \%$ natural fiber $+2 \%$ ancient admixture, $0.4 \%$ natural fiber $+4 \%$ ancient admixture were added into the mix and $0.6 \%$ natural fiber $+6 \%$ ancient admixture were added into the mix and conducted a test on mixed concrete and nominal concreting for knowing the strength behavior of structure with comparing nominal mix of concrete. Different age of results

Table -3: Compressive Strength for 7 days of curing

\begin{tabular}{|c|c|c|c|c|}
\hline Mix & $\begin{array}{c}\text { Natural } \\
\text { Fibre } \\
(\%)\end{array}$ & $\begin{array}{c}\text { Ancient } \\
\text { admixture } \\
(\%)\end{array}$ & $\begin{array}{c}\text { Mean } \\
\text { Load } \\
(\mathbf{k N})\end{array}$ & $\begin{array}{c}\text { Compression } \\
\text { Strength } \\
\left(\mathbf{N} / \mathbf{m m}^{2}\right)\end{array}$ \\
\hline Nominal & $\mathbf{0}$ & $\mathbf{0}$ & $\mathbf{4 5 4 . 5}$ & $\mathbf{2 0 . 2}$ \\
\hline EC1 & $\mathbf{0 . 2}$ & $\mathbf{2}$ & $\mathbf{5 9 4}$ & $\mathbf{2 6 . 4}$ \\
\hline EC2 & $\mathbf{0 . 4}$ & $\mathbf{4}$ & $\mathbf{6 6 6 . 5}$ & $\mathbf{2 9 . 6}$ \\
\hline EC3 & $\mathbf{0 . 6}$ & $\mathbf{6}$ & $\mathbf{6 9 9 . 5}$ & $\mathbf{3 1 . 1}$ \\
\hline
\end{tabular}

In the above result of 7 days of compression test results with comparing nominal mix of concrete. The compression strength of $\mathrm{EC} 1$ is $30 \%$ greater than the nominal mix of concrete. The compression strength of EC2 is $46 \%$ greater 
than the nominal mix of concrete. The compression strength of EC3 is $54 \%$ greater than the nominal mix of concrete

Table -4: Compression strength for 28 days of curing

\begin{tabular}{|c|c|c|c|c|}
\hline Mix & $\begin{array}{c}\text { Natural } \\
\text { Fibre } \\
(\%)\end{array}$ & $\begin{array}{c}\text { Ancient } \\
\text { admixture } \\
(\%)\end{array}$ & $\begin{array}{c}\text { Mean } \\
\text { Load } \\
(\mathbf{k N})\end{array}$ & $\begin{array}{c}\text { Compression } \\
\text { Strength } \\
\left(\mathbf{N} / \mathbf{m m}^{2}\right)\end{array}$ \\
\hline Nominal & $\mathbf{0}$ & $\mathbf{0}$ & $\mathbf{5 3 0}$ & $\mathbf{2 3 . 5}$ \\
\hline EC1 & $\mathbf{0 . 2}$ & $\mathbf{2}$ & $\mathbf{6 5 5}$ & $\mathbf{2 9 . 1}$ \\
\hline EC2 & $\mathbf{0 . 4}$ & 4 & $\mathbf{7 2 0}$ & $\mathbf{3 2 . 4}$ \\
\hline EC3 & $\mathbf{0 . 6}$ & $\mathbf{6}$ & $\mathbf{8 2 0}$ & $\mathbf{3 6 . 8}$ \\
\hline
\end{tabular}

In the above result of 28 days of compression test results with comparing nominal mix of concrete. The compression strength of EC1 is $23 \%$ greater than the nominal mix of concrete. The compression strength of EC2 is $36 \%$ greater than the nominal mix of concrete. The compression strength of EC3 is $55 \%$ greater than the nominal mix of concrete.

\subsection{Bending Strength}

Specimens are tested at the age of 7 days, 28 days and their test results are tabulated in Table -5 Table -6 respectively.

Table - 5: Flexural strength for 7 days of curing

\begin{tabular}{|c|c|c|c|c|}
\hline Mix & $\begin{array}{c}\text { Natural } \\
\text { fiber } \\
(\%)\end{array}$ & $\begin{array}{c}\text { Ancient } \\
\text { admixture } \\
(\%)\end{array}$ & $\begin{array}{c}\text { Mean } \\
\text { load } \\
(\mathbf{k N})\end{array}$ & $\begin{array}{c}\text { Flexural } \\
\text { strength } \\
\left(\mathbf{N} / \mathbf{m m}^{2}\right)\end{array}$ \\
\hline Nominal & $\mathbf{0}$ & $\mathbf{0}$ & 7.5 & 3.75 \\
\hline EC1 & 0.2 & 2 & 9.5 & 4.75 \\
\hline EC2 & $\mathbf{0 . 4}$ & 4 & 11 & 5.5 \\
\hline EC3 & $\mathbf{0 . 6}$ & 6 & 12 & 6 \\
\hline
\end{tabular}

In the above result of 7 days of flexural test results with comparing nominal mix of concrete. The bending strength of EC1 is $26 \%$ greater than the nominal mix of concrete. The bending strength of EC2 is $46 \%$ greater than the nominal mix of concrete. The bending strength of EC3 is $60 \%$ greater than the nominal mix of concrete

Table -6: Bending strength for 28 days of curing

\begin{tabular}{|c|c|c|c|c|}
\hline Mix & $\begin{array}{c}\text { Natural } \\
\text { fiber } \\
(\%)\end{array}$ & $\begin{array}{c}\text { Ancient } \\
\text { admixture } \\
(\%)\end{array}$ & $\begin{array}{c}\text { Mean } \\
\text { load (kN) }\end{array}$ & $\begin{array}{c}\text { Flexural } \\
\text { strength } \\
\left(\mathbf{N} / \mathbf{m m}^{2}\right)\end{array}$ \\
\hline Nominal & 0 & 0 & 9 & 4.5 \\
\hline EC1 & 0.2 & 2 & 12 & 6 \\
\hline EC2 & 0.4 & 4 & 13 & 6.5 \\
\hline EC3 & 0.6 & 6 & 15 & 7.5 \\
\hline
\end{tabular}

In the above result of 28 days of bending strength test results with comparing nominal mix concrete. The strength of flexure in $\mathrm{EC} 1$ is $33 \%$ greater than nominal mix concrete .The strength of flexure in EC2 is $44 \%$ greater the than nominal mix concrete. The strength of flexure in EC3 is $66 \%$ greater the than nominal mix of concrete. Here we are producing the test results of final strength of concrete because 28 day strength has a 99 percent of concrete final strength. So we can make this test results as final results.

\subsection{Split Tensile Strength}

Specimens were tested at the sequence of days as 7,28 number of days and their test results are tabulated in Table 7 Table -8 respectively.

Table -7: Split tensile strength for 7 days of curing

\begin{tabular}{|c|c|c|c|c|}
\hline Mix & $\begin{array}{c}\text { Natural } \\
\text { fiber } \\
(\%)\end{array}$ & $\begin{array}{c}\text { Ancient } \\
\text { admixture } \\
(\%)\end{array}$ & $\begin{array}{c}\text { Mean } \\
\text { load in } \\
\text { kN }\end{array}$ & $\begin{array}{c}\text { Split } \\
\text { tensile } \\
\text { strength } \\
(\mathbf{N} / \mathbf{m m} 2)\end{array}$ \\
\hline Nominal & $\mathbf{0}$ & $\mathbf{0}$ & $\mathbf{6 0}$ & $\mathbf{0 . 8 4}$ \\
\hline EC1 & $\mathbf{0 . 2}$ & 2 & 100 & 1.41 \\
\hline EC2 & $\mathbf{0 . 4}$ & 4 & 110 & 1.55 \\
\hline EC3 & 0.6 & 6 & 145 & 2.05 \\
\hline
\end{tabular}

In the above result of 7 days of split tensile test results with comparing nominal mix concrete. The tensile strength of $\mathrm{EC} 1$ is $67 \%$ greater than the nominal mix concrete. The tensile strength of EC2 is $84 \%$ greater than the nominal mix concrete. The tensile strength of EC3 is $60 \%$ greater than the nominal mix of concrete

Table -8: Split tensile strength for 28 days of curing

\begin{tabular}{|c|c|c|c|c|}
\hline Mix & $\begin{array}{c}\text { Natural } \\
\text { fiber } \\
(\%)\end{array}$ & $\begin{array}{c}\text { Ancient } \\
\text { admixture } \\
(\%)\end{array}$ & $\begin{array}{c}\text { Mean } \\
\text { load in } \\
\text { kN }\end{array}$ & $\begin{array}{c}\text { Split } \\
\text { tensile } \\
\text { strength } \\
(\mathbf{N} / \mathbf{m m 2})\end{array}$ \\
\hline Nominal & 0 & 0 & 80 & 1.13 \\
\hline EC1 & 0.2 & 2 & 100 & 1.41 \\
\hline EC2 & 0.4 & 4 & 115 & 1.62 \\
\hline EC3 & 0.6 & 6 & 150 & 2.12 \\
\hline
\end{tabular}

In the above result of 28 days of flexural test results with comparing nominal mix concrete. The bending strength of $\mathrm{EC} 1$ is $33 \%$ greater than the nominal mix concrete. The bending strength of EC2 is $44 \%$ greater than the nominal mix concrete. The bending strength of EC3 is $66 \%$ greater than the nominal mix of concrete

\section{CONCLUSIONS}

\section{Introduction}

From the investigation the overall objective of the work was feasible of incorporating Natural fiber and ancient admixture as an additive material to concrete mix. This experiment includes the preparation of concrete mixes containing natural coir fibre and ancient admixture and study the concrete properties improvement in cube compressive strength, bending strength and tensile strength.

\section{Main conclusion of study}

According to this experimental study following conclusion have been arrived. The behaviour properties like compression strength, bending strength, tensile strength has increased to a appreciable value. The compression strength of mix A with $0.2 \%$ natural fiber and $2 \%$ ancient admixture increased $30 \%$ compression strength compare nominal mix of concrete in 7 number of days for curing period. The 28 
number of days for cube compressive strength of concrete with $\mathrm{EC} 1(0.2 \%$ natural fiber $+2 \%$ ancient admixture $)$ was $29.1 \mathrm{~N} / \mathrm{mm} 2$ which was lower than $32.4 \mathrm{~N} / \mathrm{mm} 2$ of concrete with EC2 (0.4\% natural fiber $+4 \%$ ancient admixture). From above condition we identify the compression strength of concrete increased by increasing natural fiber and ancient admixture percentage. The flexural strength test and split tensile strength indicated positive results in concrete with increasing percentage of natural fiber and ancient admixture compare to control concrete. The ultimate conclusion is that, concrete with natural fiber and ancient admixture can used as an admixture in structural and non-structural elements. This offers a solution reducing wastage from industries like coconut oil industries.

\section{Recommendation for further research}

The following recommendations are proposed for further research and study in order to form a complete usage of waste material in concrete mixes: The durability of concrete with coir fiber need comprehensive researches. Further research is needed to determine coir fibre used as reinforcement in structural element. The effect of curing with air and water on the concrete specimens. Field study is needed to show the social acceptance of using concrete containing coir fibre and egg albumen.

\section{REFERENCES}

[1]. Aggarwal, L. K. (1992). "Studies on cement-bonded coir fibre boards." Cement and Concrete Composites, 14(1), 63-69.

[2]. Agopyan, V., Savastano Jr, H., John, V. M., and Cincotto, M. A. (2005). "Developments on vegetable fibrecement based materials in Sa?o Paulo, Brazil: An overview." Cement and Concrete Composites, 27(5), 527536.

[3]. Asasutjarit, C., Hirunlabh, J., Khedari, J., Charoenvai, S., Zeghmati, B., and Shin, U. C. (2007). "Development of coconut coir-based lightweight cement board." Construction and Building Materials, 21(2), 277-288.

[4]. Baruah, P., and Talukdar, S. (2007). "A comparative study of compressive, flexural, tensile and shear strength of concrete with fibres of different origins." Indian Concrete Journal, 81(7), 17-24.

\section{BIOGRAPHIES}

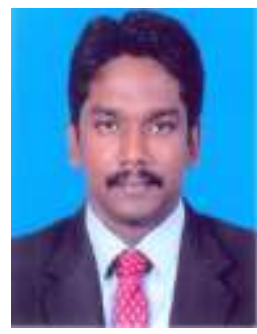

Mr. S.KARTHIKEYAN, M-Tech. He is currently working as Assistant professor-I in the Department of Civil Engineering at Velammal Engineering college, Chennai, Tamil Nadu. His area of research work is study of beamcolumn joint. Email id: karthikeyanstructure@gmail.com

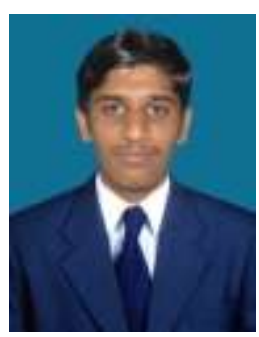

Mr. A A ELANGOVAN, M-Tech. He is currently working as Assistant professor in the Department of Civil Engineering at GRT Institute of Engineering and Technology, Thiruttani, Tamil Nadu. His area of research work is strengthening of concrete by using low cost materials. Email id:elangovanaa@yahoo.com 